\title{
THE RELATIONSHIPS BETWEEN ORGANIZATION SYSTEMS AND HUMAN RESOURCE MANAGEMENT PRACTICES IN THE MALAYSIAN HOTEL ORGANIZATIONS
}

\author{
Syed Munir Barakbah Syed Faozi Barakbah, Azrin Abdul Razak and \\ May May Grace Derioh \\ UNITAR International University, Malaysia
}

Fakhrulzaman Abdullah

Suliman Al-Rajhi Colleges, United Arab Emirates

\begin{abstract}
Hotel organizations are made up of systems, processes and procedures, structure, and people. The organizational effectiveness depends on the appropriateness of those variables as well as the Human Resources Management (HRM) functions and practices. The HRM practices specifically relate to how people should be treated and managed, and current thinking strongly believes that human resources are uniquely important in sustaining the hotels' long-term growth and success. The objectives of the research were to examine the relationships among organizational systems, HRM practices, and organizational structure orientations of the hotel organizations in Malaysia. The variables were examined in 21 hotels that were rated as either 4 or 5 star. The organizational system's orientation indicated a slight inclination towards flexibility as supported by the slightly open information flow, a balance between defined and flexible job assignments, and also some the lack of employees' understanding of their job functions which exerted a pull against flexibility. The HRM practices orientation showed a preference for a mix between individual and group approaches and the organizational structure appeared to be slightly open with some conservative practices while some seemed to be leaning towards proactiveness. Overall, there was an average or above-average fit between the three variables in a majority of the hotels examined.

Key words: Organizational systems, hard HRM, alignment, formalization, organizational structure, processes.

Cite this Article: Syed Munir Barakbah Syed Faozi Barakbah, Azrin Abdul Razak, May May Grace Derioh, Fakhrulzaman Abdullah, The Relationships between Organization Systems and Human Resource Management Practices in the Malaysian Hotel Organizations, International Journal of Management, 11(12), 2020, pp 772-784.

http://iaeme.com/Home/issue/IJM?Volume=11\&Issue=12
\end{abstract}




\section{INTRODUCTION}

The organization is made up of systems, processes, structures, and people. Organizational effectiveness depends on the appropriateness of systems, structure, and processes as well as the functional aspects, but ultimately it rests on the quality of human resources operating within the organization (Amin et al., 2014). Additionally, the ability of HR to function optimally depends on three factors: organizational systems, human resource practices, and the structural orientation of the organization (Zhang, 2016). This will determine to a large extent on the readiness of the organization to implement its competitive and business plans.

The overall objective of the research was to examine the relationships among organizational systems, and HRM practices in the hotel organizations in Malaysia. The specific objectives are to examine if there were similarities and differences in the orientations and to determine if there were any associations among those variables orientations with the turnover rates in the hotel organizations.

\subsection{Study Proposition}

- It is proposed that there is no relationship between the organization systems and processes with the soft HRM practices in the 4- and 5-star hotel organizations, or

- The higher the hotel required the conformance to systems and processes, the lower will be the approach to the soft aspects of the HRM practices.

The study would enrich the body of knowledge on HRM practices in both theory development and HRM strategic orientations for the hotel organizations. The identified factors from the study will help academicians and practitioners understand and appreciate the important roles of HR in ensuring organizational effectiveness. The hotel organization systems orientation was identified through its processes and procedures. The HRM practices focused on the functional orientations, and the organizational structure examined the nature of tasks and responsibilities allocation among individuals and departments. It was proposed that when there is a high level of association among the three strategic systems orientations, the organization will be more effective as indicated by the low employees' turnover rate (Harney, 2009).

\section{OVERVIEW OF LITERATURE}

\subsection{Systems Theory}

Modern management is characterized by two characteristics of organizations. The system's characteristics (1) embedded in a broader system by the context in which they operate; and (2) interdependence between elements that will result in a change in another (Wright \& Snell, 1991). Organizations are pictured as "input-transformation-output systems" that compete for resources. According to Wright and McMahon (1992), the HRM should not be viewed as a one-off structural intervention, but as an ongoing process concerned with balancing emerging contradictions of the employment relationship, which means identifying a good strategy for marketing its outputs (products and services), obtaining necessary resources, and dealing with external threats.

Survival and prosperity also depend on the efficiency of the transformation process used by the organization to produce its goods and services, on worker motivation, and on cooperation. Beer et al. (1984) stressed an awareness of HRM from a holistic point of view, incorporating multiple stakeholder interests, with various prospective outcomes, ranging from individual to societal. The efficiency of the transformation process is increased by finding more rational ways to organize and perform the work and by deciding how to make the best use of available technology, resources, and personnel (Edwards et al., 2013). The top 
management has primary responsibility for designing an appropriate organizational structure, determining authority relationships, and coordinating operations across specialized subunits of the organization (Yuki, 1994). A system can survive only when it delivers an output that can be exchanged for new inputs as well as for maintaining the system. This involves work on national business systems, systems of industrial relations, and varying institutional factors across nations and cultures (Wilkinson \& Wood, 2017).

Zedeck and Cascio (1984) indicated that systems theory has shown specific promise in research which has limited context and the determinants of HRM. The systems approach emerged as scientists and philosophers identified common themes in the approach to managing and organizing complex systems. Cascio (1992) acknowledged four major concepts underlie the systems approach: (1) Specialization - a system is divided into smaller components allowing more specialized attention on each component, (2) Grouping - to avoid generating greater density with increasing specialization, it becomes necessary to group related disciplines or sub-disciplines, (3) Coordination - as the components of a system are grouped, it is necessary to coordinate the interactions among the group, and (4) Emergent Properties - dividing a system into subsystems (groups of parts within the system) requires recognizing and understanding the 'emergent properties' of a system; that is, recognizing why the system as a whole is greater than the sum of its parts.

Tichy, Fombrun, and Devanna (1982) stated that the HRM functional practices focused on the procedural aspects of the HRM functions. The generic functions performed by the HRM divisions of any firm which are termed as "Hard" HRM are HR planning, staffing, training and development, appraisal and evaluation, and compensation. Legge (1995) remarked that the hard HRM approach had some similarity with scientific management as people are reduced to passive objects that are not cherished as a whole person, but measured on whether they possess the skills/attributes the organization requires. The 'hard' model, according to Tichy, Fombrun and Devanna (1982); Fombrun, Tichy, and Devanna (1984); and Hendry and Pettigrew (1986) were that HR was mainly considered as a factor of production, or a variable cost of doing business, whose supply should alter with the product market demand.

Dalton et al. (1980) believed organization structure as the anatomy of the organization which provides a foundation within which the organization functions and it affects the behavior of organization members. Perrow (1967) referred to structure as an organizational setting where the individual member must work together with others, with arrangements or relationships that enable coordination and control of work. Organizational structure, according to Child (1972), was the descriptions of the allocation of tasks and responsibilities among individuals and departments, it designates the nature and means of formal reporting relationships, as well as the groupings of individuals within the organization. Schaffer (1984) considered it as comprehending the parameters which defined the way an organization is assembled. He added that it is through an organization's structure that a framework for integrating the organization's strategic plans for the allocation of its resources is achieved. The organizational structure then referred to the way organizations organize their work. Olsen, West, and Tse (1998) revealed that conceptually, it can be defined as composing of the following elements: the degree of centralization, formalization, complexity, configuration, and flexibility in the firm.

\section{RESEARCH METHODOLOGY}

The case study design was selected since the objectives of the study were to understand the hotel organizations' systems orientations and how it relates to organizational effectiveness. The variables were examined in 21 hotels that were rated as either 4 or 5-star. Primary data were collected via mail survey over 3 weeks. The respondents represent those holding at least 
an executive-level position in the human resource management department/division of the hotel. Secondary information is derived from research reports (thesis, and journal articles) and published data by Tourism Malaysia, Ministry of Tourism, and Economic Reports.

Two instruments were required for the study and they were: (1) organizational system, and (2) HRM functional practices. Questions on the respondents' profiles are included to ensure the reliability of responses. These two instruments were compiled in the form of a questionnaire that was mailed to the hotels. For the first three variables, a 4-point Likert-like scale was used to tap the extent that each practice was applied in the hotels.

The organizational system's orientation was measured on 4 dimensions: (1) information flow, (2) job scope, (3) task and procedures, and (4) customer focus (4). The HRM functional practices orientation was tapped using the following 5 dimensions: (1) HR planning, (2) staffing, (3) training and development, (4) appraisals, and (5) compensation. The organizational structure orientation was determined by 3 dimensions: (1) formalization, (2) centralization, and (3) complexity. Performance outcome was measured by the hotels' front liner employees (housekeeping, restaurants, and front office areas) turnover rates.

\section{STUDY FINDINGS}

An analysis of the profile of respondents in the 21 hotels indicated that $67 \%$ of the respondents held positions as either personnel executive or training manager, $19 \%$ were human resource managers, while $14 \%$ were HR supervisors. The average number of guest rooms available for sale was 395 rooms and the total average number of full-time employees was 190 of which 63 employees or 33\% were front liners.

The 4 dimensions for measuring the organizational system's orientation were information flow, job scope, tasks and procedures, and customer focus. Information flow indicated the direction of the information flow and the degree of information exchange. The first item measured the degree of information exchange and results indicated some limited information exchange among employees. On the degree of information filtering from management to employees, there was a balance between the amounts of information that got filtered down compared to those that were unfiltered. On a positive note, the organizations were somewhat proactive in seeking employees' suggestions. Thus, overall there was a slightly open information flow in the organizations.

Table 1 Information Flow Variable

\begin{tabular}{|l|l|c|l|}
\hline No & \multicolumn{1}{|c|}{ Factors } & $\begin{array}{c}\text { Mean } \\
\text { Score }\end{array}$ & \multicolumn{1}{|c|}{ Level } \\
\hline 1 & Information exchange & 2.33 & $\begin{array}{l}\text { Limited exchange of } \\
\text { information }\end{array}$ \\
\hline 2 & Information from management & 2.52 & Some information is filtered \\
\hline 3 & Employees' suggestions & 2.95 & Organization seek suggestions \\
\hline & Information Flow & 2.60 & Relatively transparent \\
\hline
\end{tabular}

Job scope specifically addressed the nature of the employees' tasks and job descriptions. Six items are used to determine the tasks' orientation. The first item indicated that the tasks were slightly broad with no overlapping of functions assigned to employees, and job duties appeared to be slightly flexible. Employees clearly understood their job descriptions. However, there was some tendency for misunderstanding among the employees since they were often assigned to other departments, in support of the cross-functional work team. Overall, the job functions indicated a balance between defined job descriptions and task flexibility. 
Syed Munir Barakbah Syed Faozi Barakbah, Azrin Abdul Razak, May May Grace Derioh, Fakhrulzaman Abdullah

Table 2 Job Scope Variables

\begin{tabular}{|c|l|c|l|}
\hline No & \multicolumn{1}{|c|}{ Factors } & Mean Score & \multicolumn{1}{c|}{ Level } \\
\hline 1 & Scope of tasks & 3.45 & Very specific and limited \\
\hline 2 & Overlapping of functions & 2.05 & No overlapping \\
\hline 3 & Job duties & 2.57 & Somewhat flexible \\
\hline 4 & Job descriptions & 2.43 & Relatively clear \\
\hline 5 & $\begin{array}{l}\text { Employees understanding of their job } \\
\text { functions }\end{array}$ & 1.57 & Very clear \\
\hline 6 & Assignment to other departments & 3.38 & $\begin{array}{l}\text { Multi skill - often assigned to } \\
\text { other departments }\end{array}$ \\
\hline & Job Scope & 2.58 & $\begin{array}{l}\text { Relatively specific with some } \\
\text { flexibility }\end{array}$ \\
\hline
\end{tabular}

Tasks and procedures were related to the extent of routines and the degree of customers' interactions required. These were measured on six items. The first item measured whether customers' response time could be standardized. Table 3 showed that generally, it could not be standardized since there was a need for high interactions between employees and customers. However, there were quite a several tasks that were routine that could be automated. Systematic procedures for some tasks are somewhat available and the organizations also indicated they were unable to provide training for non-routine tasks. Overall, there was very minimal orientation toward systematic tasks and procedures.

Table 3 Tasks and Procedures Variable

\begin{tabular}{|c|l|c|l|}
\hline No & \multicolumn{1}{|c|}{ Factors } & Mean Score & \multicolumn{1}{c|}{ Level } \\
\hline 1 & Customer response time & 3.29 & Relatively fast \\
\hline 2 & Automated Jobs & 3.24 & Quite automated \\
\hline 3 & Procedures & 2.24 & Relatively Systematic \\
\hline 4 & Jobs & 1.71 & Very Routine \\
\hline 5 & Training provided for other tasks & 1.71 & Not provided \\
\hline 6 & Requirement for interaction & 3.33 & Required \\
\hline & Tasks and Procedures & 2.59 & Quite systematic and routine \\
\hline
\end{tabular}

The customer focus variable was designed to measure the organization's systems orientation in relation to the handling of its customer-related activities. 4 items are combined to indicate the orientation. The first item was aimed at finding out the rate of employees responds to customers' needs. Results indicated that generally, the organizations felt that their employees are responding quite well to customers' needs and that employees also clearly understood the customer's needs. The third item was intended to determine whether employees were sure of what to do when there were a large number of customers and here, there were some slight job uncertainties in instances where the employees were faced with such situations. The hotel organizations were moderate in encouraging employees' creativity in their attempt to meet customers' needs. Thus, it was concluded that the hotel organizations were slightly customers' focus and that they were able to meet customers' needs in normal workflow situations.

Table 4 Customer Focus Variable

\begin{tabular}{|l|l|c|l|}
\hline No & \multicolumn{1}{|c|}{ Factors } & $\begin{array}{c}\text { Mean } \\
\text { Score }\end{array}$ & \multicolumn{1}{|c|}{ Level } \\
\hline 1 & Employees' response to customers' needs & 3.43 & Very fast response \\
\hline 2 & Understanding Customers' needs & 3.38 & Clearly understood \\
\hline 3 & Customers arrival time & 2.86 & Quite knowledgeable \\
\hline 4 & Employees encourage to be creative & 2.57 & Somewhat encouraged \\
\hline & Customer Focus & 3.06 & $\begin{array}{l}\text { Oriented towards } \\
\text { customer focus }\end{array}$ \\
\hline
\end{tabular}


The Relationships between Organization Systems and Human Resource Management Practices in the Malaysian Hotel Organizations

The overall organizational systems orientation indicated a slight inclination towards flexibility as indicated in Table 5 and Illustration 1 . This was supported by the slightly open information flow, as it was related to the readiness of management in accommodating employees' suggestions. The job scope function indicated a balanced inclination between defined and flexibility, where jobs were slightly broad and employees were often assigned to other departments. However, the lack of employees' understanding of their job functions exerted a pull against flexibility.

Table 5 Organizational Systems Orientation

\begin{tabular}{|l|l|c|l|}
\hline No & \multicolumn{1}{|c|}{ Factors } & Mean Score & \multicolumn{1}{c|}{ Level } \\
\hline 1 & Information Flow & 2.60 & Relatively transparent \\
\hline 2 & Job Scope & 2.58 & $\begin{array}{l}\text { Relatively specific with some } \\
\text { flexibility }\end{array}$ \\
\hline 3 & Task and Procedures & 2.59 & Quite specific and routine \\
\hline 4 & Customer Focus & 3.06 & $\begin{array}{l}\text { Oriented towards strong } \\
\text { customer focus }\end{array}$ \\
\hline & Organizational Systems & 2.70 & Oriented towards Open System \\
\hline
\end{tabular}

\section{Illustration 1: Organizational Systems orientation}

\begin{tabular}{|c|c|c|c|}
\hline \multicolumn{4}{|c|}{ Task and Procedures } \\
\hline 1 & 2 & 3 & 4 \\
\hline Routine & 2.59 & \multicolumn{2}{|c|}{ High Interaction } \\
\hline \multicolumn{4}{|c|}{ Information Flow } \\
\hline 1 & 2 & 3 & 4 \\
\hline Limited & 2.60 & \multicolumn{2}{|c|}{ Transparent } \\
\hline \multicolumn{4}{|c|}{ Job Scope } \\
\hline 1 & 2 & 3 & 4 \\
\hline Defined & 2.58 & \multicolumn{2}{|c|}{ Flexible } \\
\hline \multicolumn{4}{|c|}{ Customer Focus } \\
\hline 1 & 2 & 3 & 4 \\
\hline Organization & & 3.06 & Customer \\
\hline \multicolumn{4}{|c|}{ ORGANIZATIONAL SYSTEM } \\
\hline 1 & 2 & 3 & 4 \\
\hline Fixed & 2.73 & & \\
\hline
\end{tabular}

Hard HRM Practices focused on the procedural aspects of the HRM functions. The generic functions that are performed by the HRM divisions of any firm are the HR planning, staffing, training and development, appraisal and evaluation, and compensation. As indicated before, the HRM Practices or the "Hard" HRM practices orientation was measured on those 5 functional area dimensions. As illustrated in Table 6, the overall mean score for Human resource planning was 2.24. This indicated that there were some mixtures in the orientation as can be observed from the mean scores for the individual items. A score that is closer to 1 would indicate an inclination towards some degree of conservatism or reactivity in the approach in human resource planning. It appeared that planning was quite formalized as indicated by the mean score of 1.81. Planning did not quite consider the business development of the organization judging from the mean score of 1.76, and career ladders were not established as indicated by the mean score of 1.91 . The respondents indicated that the HR 
Syed Munir Barakbah Syed Faozi Barakbah, Azrin Abdul Razak, May May Grace Derioh, Fakhrulzaman Abdullah

department had a major part in determining the HR requirements of the organization and there were mixed opinions on the planning horizon.

Table 6 HR Planning

\begin{tabular}{|l|l|c|l|}
\hline No. & \multicolumn{1}{|c|}{ Dimensions } & $\begin{array}{c}\text { Mean } \\
\text { Score }\end{array}$ & \multicolumn{1}{|c|}{ Level } \\
\hline 1 & Planning is formalized & 1.81 & Quite formalized \\
\hline 2 & $\begin{array}{l}\text { Planning considers business } \\
\text { development }\end{array}$ & 1.76 & $\begin{array}{l}\text { Did not quite consider the } \\
\text { business development }\end{array}$ \\
\hline 3 & Establish career ladders & 1.91 & Not clearly established \\
\hline 4 & HR Department plans HR requirements & 3.05 & HR played a major role \\
\hline 5 & Planning duration over 1 year period & 2.67 & $\begin{array}{l}\text { Somewhat mixed - oriented } \\
\text { towards formal and short term }\end{array}$ \\
\hline & Overall Mean & 2.24 & $\begin{array}{l}\text { Some inclination towards } \\
\text { reactive. }\end{array}$ \\
\hline
\end{tabular}

The staffing function was rated as average with a mean score of 2.52, as shown in Table 7 . This indicated that there might be some differences in orientations on the 5 items. The respondents felt that the promotional criteria were somewhat transparent as indicated by the mean score of 3.24. However, they also indicated that the opportunities for promotion were quite limited (mean score of 1.71) even though management did discuss career development with the employees as evidence by the relatively high score of 3.24. Respondents generally felt that employees are allowed to nominate themselves for promotion (mean score of 2.38), and the organizations did not place a strong emphasis on external hiring as indicated by the mean score of 2.05 .

Table 7 Staffing

\begin{tabular}{|l|l|c|l|}
\hline No. & \multicolumn{1}{|c|}{ Dimensions } & $\begin{array}{c}\text { Mean } \\
\text { Score }\end{array}$ & \multicolumn{1}{|c|}{ Level } \\
\hline 1 & Explicit Promotional criteria & 3.24 & Quite explicit - transparent \\
\hline 2 & Promotional opportunities & 1.71 & Somewhat limited \\
\hline 3 & $\begin{array}{l}\text { Career development - participation } \\
\text { by Management }\end{array}$ & 3.24 & $\begin{array}{l}\text { High level of management } \\
\text { participation }\end{array}$ \\
\hline 4 & Self-nomination for promotion & 2.38 & Somewhat allowed \\
\hline 5 & Emphasize external hiring & 2.05 & Quite a low emphasis \\
\hline & Overall Mean & 2.52 & $\begin{array}{l}\text { Mixed - More fixed and } \\
\text { limited with a slight } \\
\text { orientation towards } \\
\text { employees }\end{array}$ \\
\hline
\end{tabular}

As illustrated in Table 8, the mean score for the training and development function was 2.16 which indicated, to some extent, the inclination towards conservativeness in this functional approach. 5 items were used to measure this variable. The first item was the design of the job requirement, which was rated at 2.05. This indicated that the training and development programs were offered mainly to address current job requirements. The next item also relates to the inclination of the training and development programs. The mean score was much lower which indicated that the programs were developed based also on responding to current needs. These training and development programs were mainly initiated by the top management or the HR department, rather than the individual departments. The emphasis of the programs was on the productivity needs of the organizations (mean score of 1.67). Some programs invited volunteers for participation while others were designed for specific employee groups, as reflected by the mean score of 2.67. The programs were quite specifics that were targeted to meet certain goals as indicated by the mean score of 3.29 . 
The Relationships between Organization Systems and Human Resource Management Practices in the Malaysian Hotel Organizations

Table 8 Training and Development

\begin{tabular}{|l|l|c|l|}
\hline No. & \multicolumn{1}{|c|}{ Dimensions } & $\begin{array}{l}\text { Mean } \\
\text { Score }\end{array}$ & \multicolumn{1}{|c|}{ Level } \\
\hline 1 & $\begin{array}{l}\text { Designed on the current job } \\
\text { requirement }\end{array}$ & 2.05 & $\begin{array}{l}\text { Focus on the current job } \\
\text { requirement }\end{array}$ \\
\hline 2 & Based on current needs & 1.57 & Focus on current needs only \\
\hline 3 & Determination of programs & 1.71 & $\begin{array}{l}\text { Mainly by HR/Top } \\
\text { management }\end{array}$ \\
\hline 4 & Programs emphasis & 1.67 & Mainly on productivity needs \\
\hline 5 & Participation in programs & 2.67 & Somewhat opened \\
\hline 6 & Knowledge-based objectives & 3.29 & Very specific target \\
\hline & Overall Mean & 2.16 & $\begin{array}{l}\text { Slight inclination towards } \\
\text { current needs }\end{array}$ \\
\hline
\end{tabular}

As indicated in Table 9, the appraisal function was given an overall moderate rating with a mean score of 2.44. 8 items were used to measure the orientation of the appraisal function. The first item was the extent to which the respondents felt that the wages commensurate with performance. Here, the mean score was 2.57 which indicated that they felt that the wages were somewhat in line with performance. On the opportunity for self-evaluation, the score was slightly higher which meant that the employees were allowed some opportunity to rate themselves. When asked whether the evaluation process was informal or formal, the responses were mixed. A majority (3.29) of the responses indicated that it was an on-going process. The employees were, however, evaluated mainly as individuals rather than as groups. They also felt that the appraisal was mainly not used for performance improvement, but It was used mainly for reward and remedial purposes as indicated by the mean score of 1.81. Also, employees were often not provided with feedback on their performance.

Table 9 Appraisals

\begin{tabular}{|l|l|c|l|}
\hline No. & \multicolumn{1}{|c|}{ Dimensions } & $\begin{array}{l}\text { Mean } \\
\text { Score }\end{array}$ & \multicolumn{1}{|c|}{ Level } \\
\hline 1 & $\begin{array}{l}\text { Wages commensurate with } \\
\text { performance }\end{array}$ & 2.57 & Quite commensurate \\
\hline 2 & Opportunity for self-evaluation & 2.95 & Opportunities provided \\
\hline 3 & The evaluation process is informal & 2.38 & Mixture \\
\hline 4 & The evaluation process is on-going & 3.29 & Continuous process \\
\hline 5 & Evaluated as individuals & 1.62 & $\begin{array}{l}\text { Mainly evaluated } \\
\text { individually }\end{array}$ \\
\hline 6 & $\begin{array}{l}\text { Performance Improvement - pressure } \\
\text { by management }\end{array}$ & 3.05 & Somewhat high level \\
\hline 7 & Employees are given feedback & 1.81 & Somewhat low \\
\hline 8 & $\begin{array}{l}\text { The evaluation used for reward and } \\
\text { remedial }\end{array}$ & 1.81 & Mainly for remedial \\
\hline & $\begin{array}{l}\text { Overall Mean } \\
2.44\end{array}$ & $\begin{array}{l}\text { Moderate with some } \\
\text { participation but mainly for } \\
\text { remedial needs }\end{array}$ \\
\hline
\end{tabular}

As shown in Table 10, the compensation function was overall rated as slightly below average, which meant that there was a tendency to be slightly conservative in orientation. Five items were used to measure this variable. Respondents were asked to indicate whether the compensation package as standard and fixed or flexible. They responded that it was somewhat fixed and standard as evident by the mean score of 1.91. The employees felt that their job was somewhat not secure (mean score of 1.62). The respondents indicated that wages were 
Syed Munir Barakbah Syed Faozi Barakbah, Azrin Abdul Razak, May May Grace Derioh, Fakhrulzaman Abdullah

adjusted according to seniority, but initial wages were determined by market rates. Also, the hotels did consider some long-term impacts of the compensation method that they used.

Table 10 Compensation

\begin{tabular}{|l|l|c|l|}
\hline No. & \multicolumn{1}{|c|}{ Dimensions } & $\begin{array}{c}\text { Mean } \\
\text { Score }\end{array}$ & \multicolumn{1}{|c|}{ Level } \\
\hline 1 & Nature of compensation package & 1.91 & Somewhat standard and fixed \\
\hline 2 & Job security & 1.62 & Somewhat low \\
\hline 3 & Wage adjustment & 2.19 & Mainly based on seniority \\
\hline 4 & Initial wages - market rates & 3.14 & Some extent \\
\hline 5 & $\begin{array}{l}\text { Consideration of the impact of } \\
\text { compensation }\end{array}$ & 3.10 & $\begin{array}{l}\text { Somewhat long-term impact } \\
\text { considered }\end{array}$ \\
\hline & Overall Mean & 2.39 & $\begin{array}{l}\text { Inclination towards both } \\
\text { fixed and current orientation. }\end{array}$ \\
\hline
\end{tabular}

The hard HRM practices indicated an overall moderate approach as shown in Table 11. The HR Planning function was rated at a mean score of 2.24, which indicated that there were some mix orientations as were observed from the mean scores for the individual items. The overall orientation was slightly reactive. The staffing function was rated with a mean score of 2.52 which showed that there were some differences in orientations. The overall mean score indicated a balance between fixed and flexible practices. The mean score for the training and development function was 2.16 , which indicated, to some extent, the conservative inclination. It tended to lean on meeting current requirements for skills. The appraisal function was overall rated as moderate with a score of 2.44. It showed a combination of emphasis on the individual employee and employee groups. The compensation function was rated as slightly below average which meant that there was a general tendency towards a slightly conservative orientation. It also tended to be slightly in favor of fixed practices. Thus, the overall hard HRM practices indicated the slight orientation and preference for individual and fixed approaches.

Table 11 Hard HRM Practices

\begin{tabular}{|l|l|c|l|}
\hline No. & \multicolumn{1}{|c|}{ Dimensions } & $\begin{array}{c}\text { Mean } \\
\text { Score }\end{array}$ & \multicolumn{1}{|c|}{ Level } \\
\hline 1 & HR Planning & 2.24 & Inclination towards reactive \\
\hline 2 & Staffing & 2.52 & $\begin{array}{l}\text { More fixed and limited with a slight } \\
\text { orientation towards employees }\end{array}$ \\
\hline 3 & Training and Development & 2.16 & $\begin{array}{l}\text { Slight inclination towards current } \\
\text { needs }\end{array}$ \\
\hline 4 & Appraisal & 2.44 & $\begin{array}{l}\text { Moderate with some employees' } \\
\text { participation but mainly for } \\
\text { remedial needs }\end{array}$ \\
\hline 5 & Compensation & 2.39 & $\begin{array}{l}\text { Inclination towards both fixed and } \\
\text { current orientation }\end{array}$ \\
\hline & Overall Mean & 2.35 & Mixed emphasis on the practices \\
\hline
\end{tabular}


The Relationships between Organization Systems and Human Resource Management Practices in the Malaysian Hotel Organizations

\section{Illustration 2: Organization Culture}

\begin{tabular}{|c|c|c|c|}
\hline \multicolumn{4}{|c|}{ Human Resource Planning } \\
\hline 1 & 2 & 3 & 4 \\
\hline Reactive & 2.24 & \multicolumn{2}{|c|}{ Proactive } \\
\hline \multicolumn{4}{|c|}{ Staffing } \\
\hline 1 & 2 & 3 & 4 \\
\hline Fixed/Limited & 2.52 & \multicolumn{2}{|c|}{ Flexible } \\
\hline \multicolumn{4}{|c|}{ Training and Development } \\
\hline 1 & 2 & 3 & 4 \\
\hline Current Needs & 2.16 & \multicolumn{2}{|c|}{ Future Needs } \\
\hline \multicolumn{4}{|c|}{ Appraisal } \\
\hline 1 & 2 & 3 & 4 \\
\hline Individual & 2.44 & \multicolumn{2}{|c|}{ Group } \\
\hline \multicolumn{4}{|c|}{ Compensation } \\
\hline 1 & 2 & 3 & 4 \\
\hline Fixed & 2.39 & \multicolumn{2}{|c|}{ Flexible } \\
\hline \multicolumn{4}{|c|}{ HARD HUMAN RESOURCE MANAGEMENT PRACTICES } \\
\hline 1 & 2 & 3 & 4 \\
\hline Current/Fixed & 2.35 & \multicolumn{2}{|c|}{ Future/Flexible } \\
\hline
\end{tabular}

\section{Illustration 4: Comparison of Relationships among Organizational Systems and HRM Practices}

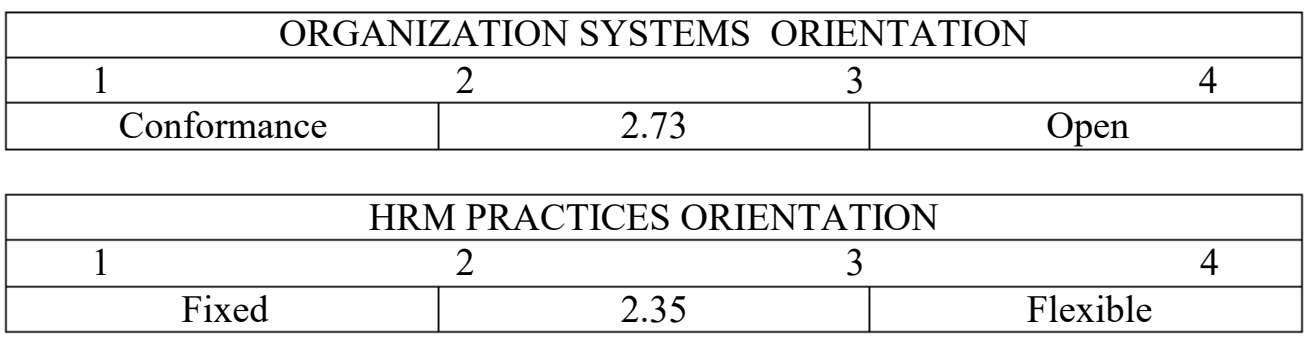

Table 12 Extent of Relationship between Organizational Systems and HRM Practices

\begin{tabular}{|l|c|c|}
\hline \multicolumn{1}{|c|}{ Factors } & Variance & Extent of Relationship \\
\hline $\begin{array}{l}\text { Organizational Systems } \\
\begin{array}{l}\text { Orientation } \\
2.70\end{array}\end{array}$ & 0.35 & Partial \\
\cline { 1 - 1 } $\begin{array}{l}\text { HRM Practices Orientation } \\
2.35\end{array}$ & $(8.75 \%)$ & Relationship \\
\hline
\end{tabular}

The variables were examined in a total of 21 hotel organizations. As indicated in Table 13, the variances amongst the mean scores for organizational systems orientation, HRM practices orientation, and organizational structure orientation were calculated, and the variances were grouped into three categories. Category 1 indicated a good fit if the variance between the two means is less than 0.26. Category 2 showed an average fit where the variance fell between 0.26 and 0.50 . Category 3 assumed a poor fit if the variance was over 0.50 . As shown in Table 13, a good fit among system, HRM practices, and structure orientation was found in a total of 10 hotels or $48 \%$, an average fit was found in 8 hotels or $38 \%$, whilst there was a poor fit in 3 hotels or 14\%. Thus, overall it can be concluded that there was an average or above- 
Syed Munir Barakbah Syed Faozi Barakbah, Azrin Abdul Razak, May May Grace Derioh, Fakhrulzaman Abdullah

average fit between the three variables in a majority of the hotels examined. The total variance in mean score for organizational systems orientation and HRM practices orientation was average at 0.37 , the variance in the mean score between organizational systems orientation and organizational structure orientation was very low indicating a good fit, and the variance in the mean score between HRM practices orientation and organizational structure orientation was average at 0.29 . Thus, overall the alignment among the three variables was considered average at 0.30 .

The turnover rates of the hotels' front-liners were also classified into three groups. Category 1 indicated a good rating where the rate was below 20\%, Category 2 was for the average rate that ranges from $20 \%$ to $25 \%$ and Category 3 was given a poor rating for the turnover rate above $25 \%$. The findings revealed that the turnover rate was considered good in 9 hotels or $43 \%$, an average rate was found in 8 hotels or $38 \%$, and a poor rate was found in 4 hotels or $19 \%$ of the samples examined.

In comparing the extent of alignment of the organizational systems orientation variables with the turnover rates as illustrated in Table 13, it was found that there was a match in only 5 of the 21 hotels or $57 \%$. Of the 5 aligned cases, 4 cases or $80 \%$ were found to have alignment where both the systems variable and the turnover were rated good and in only 1 case or $20 \%$ where both the systems variable and the turnover rates were considered average. Therefore, the proposition that there was a relationship amongst systems variable with turnover rate could not be accepted.

Table 13 Relationships amongst Organization Systems Orientation and HRM Functional with Turnover

\begin{tabular}{|c|c|c|c|c|}
\hline CASES & $\begin{array}{c}\text { (A) } \\
\text { SYSTEMS } \\
\text { ORIENTATION }\end{array}$ & $\begin{array}{c}\text { (B) } \\
\text { HRM } \\
\text { ORIENTATION }\end{array}$ & $\begin{array}{c}\text { (D) } \\
\text { VARIANCE } \\
\text { (A) AND (B) }\end{array}$ & $\begin{array}{c}\text { (H) } \\
\text { DEGREE OF } \\
\text { STRATEGIC } \\
\text { MATCH* }\end{array}$ \\
\hline 1 & 2.69 & 2.61 & 0.09 & Category 1 \\
\hline 2 & 2.85 & 2.53 & 0.32 & Category 1 \\
\hline 3 & 2.69 & 2.49 & 0.20 & Category 2 \\
\hline 4 & 2.87 & 2.38 & 0.49 & Category 2 \\
\hline 5 & 2.53 & 2.35 & 0.18 & Category 2 \\
\hline 6 & 2.68 & 2.31 & 0.37 & Category 2 \\
\hline 7 & 3.23 & 2.41 & 0.82 & Category 3 \\
\hline 8 & 2.60 & 2.38 & 0.22 & Category 1 \\
\hline 9 & 2.45 & 2.57 & 0.12 & Category 1 \\
\hline 10 & 2.56 & 2.42 & 0.14 & Category 1 \\
\hline 11 & 2.74 & 2.43 & 0.31 & Category 1 \\
\hline 12 & 2.68 & 2.34 & 0.30 & Category 1 \\
\hline 13 & 2.83 & 1.97 & 0.86 & Category 3 \\
\hline 14 & 2.68 & 2.41 & 0.27 & Category 1 \\
\hline 15 & 2.83 & 2.33 & 0.50 & Category 2 \\
\hline 16 & 2.51 & 2.34 & 0.17 & Category 1 \\
\hline 17 & 2.50 & 2.61 & 0.11 & Category 2 \\
\hline 18 & 2.68 & 2.57 & 0.11 & Category 1 \\
\hline 19 & 2.74 & 2.07 & 0.67 & Category 2 \\
\hline 20 & 2.96 & 2.18 & 0.78 & Category 3 \\
\hline 21 & 2.99 & 2.34 & 0.65 & Category 2 \\
\hline MEAN & 2.73 & 2.38 & 0.37 & \\
\hline
\end{tabular}


The Relationships between Organization Systems and Human Resource Management Practices in the Malaysian Hotel Organizations

\section{CONCLUSIONS}

The objective of the study was to examine the hotel organization systems. HRM practices orientation, and organizational structure orientation. The organizational system's orientation indicated a slight inclination towards flexibility as supported by the slightly open information flow, a balance between defined and flexible job assignments, and also some the lack of employees' understanding of their job functions which exerted a pull against flexibility. The HRM practices orientation showed a preference for a mix between individual and group approaches and the organizational structure appeared to be slightly open with some conservative practices while some seemed to be leaning towards proactiveness.

Overall, average alignment was found among the three variables, but the very minimal alignment was found between the three variables with turnover rates. However, the findings in this study have contributed to a better understanding of the practices that relate to organizational systems, HRM practices orientation, and organizational structure orientation in the hotel organizations. However, further empirical studies need to be conducted to strengthen the findings from this initial case study on 21 hotel organizations. Regardless, this study has provided insights into some human resources related practices in hotel organizations.

\section{REFERENCES}

[1] Afthanorhan, A., Foziah, H., Rusli, R., \& Khalid, S. (2019). Modeling reflective constructs in generalized structure component analysis: An application to service quality and customer satisfaction in UniSZA library. International Journal of Innovation, Creativity and Change, 7(10), 33-41.

[2] Afthanorhan, A., Foziah, H., Rusli, R., \& Khalid, S. (2019). The effect of service quality on customer satisfaction in three campuses of UniSZA. International Journal of Innovation, Creativity and Change, 7(10), 42-56.

[3] Amin, M., Wan, Ismail W.K., Abdul Rashid, S.Z., \& Selemani, R. (2014). The impact of human resource management practices on performance evidence from a public university. TQM Journal, 26, 125-142.

[4] Beer, M., Spector, B., Lawrence, P., Mills, Q., \& Walton, R. (1984). Managing human assets. New York: Free Press.

[5] Cascio, W.F. (1992). Managing Human Resources. 3rd Editions. New York: McGraw-Hill International.

[6] Child, J. (1972). Organizational structure, environment, and performance: The role of strategic choice. Sociology, 6, 1-22.

[7] Dalton, D.R., Todor, W.D., Spendolini, M.J., Fielding, G.J., \& Porter, L.W. (1980). Organization structure and performance: A critical review. The Academy of Management Review, 5 (1), 49-64.

[8] Edwards, P., Sánchez-Mangas, R., Tregaskis, O., Lévesque, C., McDonnell, A., \& Quintanilla, J. (2013). Human resource management practices in the multinational company: A test of system, societal, and dominance effects. ILR Review, 63 (3), 588-617.

[9] Fombrun, C.J., Tichy, N.M., \& Devanna, M.A. (1984). Strategic human resource management. New York: Wiley.

[10] Harney, B. (2009). Exploring the road less traveled in HRM-performance research: A critical realist alternative to big science. Paper presented at the Proceedings of the Labor and Employment Relations Association 61st Annual Meeting, San Francisco, CA.

[11] Hendry, C. \& Pettigrew, A. (1986). The practice of strategic human resource management. Personnel Review, 15 (5), 3-8. 
Syed Munir Barakbah Syed Faozi Barakbah, Azrin Abdul Razak, May May Grace Derioh, Fakhrulzaman Abdullah

[12] Legge, K. (1995). HRM: Rhetoric, reality, and hidden agendas. In Storey, J. (Eds), Human resource management: A critical text. London: Routledge.

[13] Mohamad, M., Nasir, M. N. M., Ab Ghani, N. I., \& Afthanorhan, A. (2019). Parallel mediators of place attachment and tourist satisfaction in destination attractiveness, destination loyalty and service quality. International Journal of Innovation, Creativity and Change, 7(7), 228-256.

[14] Olsen, M.D., West, J.J., \& Tse, E.C-Y. (1998). Strategic management in the hospitality industry. 2nd Editions. New York: Wiley.

[15] Perrow, C. (1967). A framework for the comparative analysis of organizations. American Sociological Review, 32, 194-208.

[16] Rahlin, N. A., Awang, Z., Afthanorhan, A., \& Aimran, N. (2019). The art of covariance based analysis in behaviour-based safety performance study using confirmatory factor analysis: Evidence from SMES. International Journal of Innovation, Creativity and Change, 7(10), 351-370.

[17] Schaffer, J.D. (1984). Strategy, organization structure, and success in the lodging industry. International Journal of Hospitality Management, 6 (1), 33-42.

[18] Tichy, N.M., Fombrun, C.J., \& Devanna, M.A. (1982). Strategic human resource management. Sloan Management Review, 24, 47-61.

[19] Wilkinson, A., \& Wood, G. (2017). Global trends and crises, comparative capitalism, and HRM. International Journal of Human Resource Management, 28 (18), 2503-2518.

[20] Wright, P.M., \& McMahon, G.C. (1992). Theoretical perspectives for human resource management. Journal of Management, 18, 295-320.

[21] Wright, P.M., \& Snell, S. (1991). Towards an integrative view of strategic human resource management. Human Resource Management Review, 1 (3), 203-205.

[22] Yuki, G.A. (1994). Leadership in organization. New Jerseys: Prentice-Hall.

[23] Zedeck, S., \& Cascio, W.F. (1984). Psychological issues in personnel decisions. Annual Review of Psychology, 35, 461-518.

[24] Zhang, L. (2016). The impact of human resource management on organizational effectiveness. Chemical Engineering Transactions, 51, 895-900. 